\title{
SISTEM PAKAR MENDIAGNOSA PENYAKIT HERPES ZOSTER DENGAN MENGGUNAKAN METODE TEOREMA BAYES
}

\author{
Hengki Tamando Sihotang ${ }^{1}$, Erwin Panggabean ${ }^{2}$, Herlina Zebua ${ }^{3}$ \\ 1,2,3 Teknik Informatika \\ STMIK Pelita Nusantara, Jl. Iskandar Muda No. 1 Medan, Sumatera Utara, Indonesia 20154
}

hengki_tamando@yahoo.com ${ }^{1}$, erwin_gb19076719@yahoo.co.id ${ }^{2}$, helinazebua95@gmail.com³

\begin{abstract}
Abstrack
Penyakit Herpes Zoster adalah salah satu penyakit kulit yang sangat susah untuk diobati dan semua orang pasti bisa mengalaminya, karakteristik penyakit ini ditandai dengan adanya vesikuler unilateral yang berkelompok dengan nyeri yang ditandai dengan radikuler sekitar dermatom. Penelitian ini bertujuan untuk membangun metode teorema bayes menggunakan Visual Basic 2008 sebagai alat bantu untuk mendiagnosa penyakit kulit. Dengan aplikasi ini tidak harus menunggu lama untuk mengantisipasi pengobatan secara cepat dan tepat. Cara menggunakan aplikasi ini yaitu admin menginputkan pertanyaan berupa gejala-gejalayang dialami oleh pasien, selanjutnya sistem akan mengolah semua jawaban pasien menggunakan metode bayes dan sistem akan mengeluarkan output berupa hasil diagnosa jenis penyakit. Sistem yang dibangun dapat membantu pasien dalam mengetahui jenis penyakit yang sedang diderita pasien dan sesuai dengan analisa pakar penyakit kulit.
\end{abstract}

Kata Kunci : Teorema Bayes, Herpes Zoster, Visual Basic 2008

\section{Abstrack}

Herpes Zoster disease is one of the most difficult skin diseases to treat and everyone can experience it, the characteristic of this disease is marked by unilateral vesicular grouped with pain marked with radicular around the dermatome. This study aims to build bayes theorem method using Visual Basic 2008 as a tool to diagnose skin diseases. With this application does not have to wait long to anticipate treatment quickly and precisely. How to use this application is the admin input questions in the form of symptoms experienced by the patient, then the system will process all the patient answers using Bayes method and the system will output the results of the diagnosis of the type of disease. The built system can help the patient in knowing the type of illness that is being suffered by the patient and in accordance with the expert analysis of skin diseases.

\section{Keywords: Bayes Theorem, Herpes Zoster, Visual Basic 2008}

\section{PENDAhUluaN}

Penyakit Herpes Zoster adalah radang kulit akut dan setempat, terutama terjadi pada orang tua yang khas ditandai dengan adanya nyeri radikuler unilateral serta timbulnya lesi vesikuler yang terbatas pada dermatom yang dipersarafi serabut saraf spinal maupun ganglion serabut saraf sensorik dari nervus kranialis. Biasanya ditandai dengan munculnya gelembung-gelembung berwarna merah seperti lepuhan-lepuhan kecil yang berkelompok pada permukaan kulit dan berair serta di barengi dengan rasa gatal serta panas. Penyakit ini akan lebih muncul jika terjadi iritasi, luka ataupun lecet dan proses penyembuhan lama. Jika penyakit Herpes Zoster dapat terdiagnosis secara cepat, maka akan memiliki lebih banyak waktu untuk melakukan persiapan untuk masa depan, dan yang lebih terpenting lagi, Anda akan mendapatkan penanganan lebih cepat yang dapat membantu sebelum penyakit nya semakin melebar.

Salah satu cara untuk mendeteksi penyakit Herpes Zoster tersebut adalah dengan memanfaatkan teknologi canggih dan modern yaitu bidang studi Artificial Intelligence (AI) yang mampu meniru kecerdasan manusia. Salah satu bagian dari kecerdasan buatan tersebut adalah sistem pakar (expert system).

Secara umum sistem pakar (expert system) adalah salah satu bidang ilmu komputer yang mendayagunakan komputer sehingga dapat berprilaku cerdas seperti manusia. Sistem ini berusaha mengadopsi pengetahuan manusia ke komputer, agar komputer dapat menyelesaikan masalah seperti yang biasa dilakukan oleh para ahli . Sistem pakar akan memberi daftar gejalagejala sampai bisa mengidentifikasikan suatu 
objek berdasarkan jawaban yang diterima. Dengan adanya sistem pakar ini diharapkan nantinya bisa membantu para masayarakat mendapatkan informasi seputar penyakit Herpes Zoster beserta diagnosanya.

Teorema Bayes menerangkan hubungan antara probabilitas terjadinya peristiwa A dengan syarat peristiwa $\mathrm{B}$ telah terjadi dan probabilitas terjadinya peristiwa $\mathrm{B}$ dengan syarat peristiwa A telah terjadi. Teorema ini didasarkan pada prinsip bahwa tambahan informasi dapat memperbaiki probabilitas. Teorema Bayes ini bermanfaat untuk mengubah atau memutakhirkan (meng-update) probabilitas yang dihitung dengan tersedianya data dan informasi tambahan.

Sistem pakar merupakan bagian dari kecerdasan buatan yang meniru penalaran manusia. Pemanfaatan teknologi memudahkan manusia untuk mengakses informasi tanpa terbatas ruang dan waktu. Pemanfaatan teknologi ini memudahkan perancangan sistem pakar mendiagnosa penyakit Kulit Herpes Zoster menggunakan Teorema Bayes. Pembuatan aplikasi diaharapkan akan memudahkan pasien untuk mendapatkan informasi tanpa harus menunggu kehadiran seorang dokter/pakar penyakit penyakit kulit, serta diharapkan akan mengurangi atau bahkan menyelesaiankan permasalahan yang ada.

\section{METODE}

1. Sistem Pakar

Sistem pakar merupakan bagian dari artificial Intelligence (AI) yang cukup tua karena sistem ini dikembangkan pada tahun 1960. Sistem pakar yang muncul pertama kali adalah General Purpose Problem Solver (GPS) yang dikembangkan Newel Simon[1].

Istilah sistem pakar berasal dari istilah knowledge-based expert system. Istilah ini muncul karena untuk memecahkan masalah, sistem pakar menggunakan pengetahuan seorang pakar yang dimasukkan ke dalam komputer. Seseorang yang bukan pakar menggunakan sistem pakar untuk meningkatkan kemampuan pemecahan masalah, sedangkan seorang pakar[1]. "Sistem pakar adalah program komputer yang merepresentasikan dan melakukan penalaran dengan pengetahuan beberapa pakar untuk memecahkan masalah atau memeberikan saran"[1]. "Sistem pakar adalah sebuah sistem yang menggunakan pengetahuan manusia dimana pengetahuan tersebut dimasukkan ke dalam sebuah komputer dan kemudian di gunakan untuk menyelesaikan masalah-masalah yang biasanya membutuhkan kepakaran atau keahlian manusia”[1].

\section{Probabilitas Bayes}

Probabilitas Bayes merupakan salah satu cara yang baik untuk mengatasi ketidakpastian data dengan menggunakan Formula Bayes yang dinyatakan dengan rumus sebagai berikut:

$\mathrm{p}(\mathrm{A} \mid \mathrm{B})=\frac{\mathrm{p}(\mathrm{B} \mid \mathrm{A}) \times \mathrm{p}(\mathrm{A})}{\mathrm{p}(\mathrm{B})}$

dengan :

$\mathrm{p}(\mathrm{A} \mid \mathrm{B})$ : probabilitas A dan B terjadi bersamasama

$\mathrm{p}(\mathrm{B} \mid \mathrm{A})$ : probabilitas $\mathrm{B}$ dan A terjadi bersamasama.

p(B) : probabilitas kejadian B

Teori Bayes sudah dikenal dalam bidang kedokteran tetapi teori ini lebih banyak diterapkan dalam logika kedokteran modern. Teori ini lebih banyak diterapkan pada hal-hal yang berkenaan dengan probabilitas serta kemungkinan dari penyakit dan gejala-gejala yang berkaitan.

Teorema Bayes merupakan metode yang baik didalam mesin pembelajaran berdasarkan data training, dengan menggunakan probabilitas bersyarat sebagai dasarnya. Metode Bayes juga merupakan suatu metode untuk menghasilkan estimasi parameter dengan menggabungkan informasi dari sampel dan informasi lain yang telah tersedia sebelumnya. Keunggulan utama dalam penggunaan Metode Bayes adalah penyederhanaan dari cara klasik yang penuh dengan integral untuk memperoleh model marginal [4]. Adapun bentuk dari Teorema Bayes untuk evidence tunggal $\mathrm{E}$ dan hipotesis ganda $\mathrm{H}_{1}, \mathrm{H}_{2}, \mathrm{H}_{3}, \ldots \ldots . . \mathrm{H}_{\mathrm{n}}$.

$p\left(H_{i} \mid E\right)=\frac{p\left(H_{i} \mid E\right) \times p\left(H_{i}\right)}{\sum_{k=1}^{n} p\left(E \mid H_{k}\right) \times p\left(H_{k}\right)} \ldots$.

Keterangan :

$\mathrm{p}\left(\mathrm{H}_{\mathrm{i}} \mid \mathrm{E}\right)=$ Probabilitas hiposesis $\mathrm{H}_{\mathrm{i}}$ terjadi jika evidence E terjadi

$\mathrm{P}\left(\mathrm{E} \mid \mathrm{H}_{\mathrm{i}}\right) \quad=$ Probabilitas munculnya evidence E, jika hipotesis $\mathrm{H}_{\mathrm{i}}$ terjadi

$\mathrm{P}\left(\mathrm{H}_{\mathrm{i}}\right) \quad=$ Probabilitas hipotesis $\mathrm{H}_{\mathrm{i}}$ tanpa memandang evidence apapun.

$\mathrm{n}=$ Jumlah hipotesis yang mungkin.

Adapun bentuk dari Teorema Bayes untuk evidence ganda $\mathrm{E}_{1}, \mathrm{E}_{2}, \mathrm{E}_{3}, \ldots \ldots . . \mathrm{E}_{\mathrm{n}}$ dan hipotesis ganda $\mathrm{H}_{1}, \mathrm{H}_{2}, \mathrm{H}_{3}, \ldots \ldots . . \mathrm{H}_{\mathrm{n}}$ adalah sebagai berikut

$p\left(H_{i} \mid E_{1}, E_{1}, E_{1} \ldots . E_{m}\right)=$

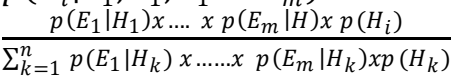

\section{Herpes Zoster}

Herpes Zoster adalah radang kulit akut dan setempat, terutama terjadi pada orang tua yang 
khas ditandai adanya nyeri radikuler unilateral serta timbul nya lesi vesikuler yang terbatas pada dermatom yang dipersarafi serabut saraf spinal maupun ganglion serabut saraf sensorik dari nervus kranialis. Infeksi ini merupakan reaktivasi virus varisela-zoster dari infeksi endogen yang telah menetap dalam bentuk laten setelah infeksi primer oleh virus[2].

Jenis-jenis penyakit Herpes Zoster:

a. Penyakit Herpes Zoster Oftalmika

Herpes zoster oftalmikus adalah infeksi virus herpes zoster yang menyerang bagian dahi dan sekitar mata dan juga menyerang ganglion gasseri yang menerima serabut saraf dari cabang oftalmikus saraf trigeminus.

b. Penyakit Herpes Zoster Servikalis

Penyakit Herpes Zoster Servikalis adalah infeksi virus yang menyerang pada bagian pundak dan lengan.

c. Penyakit Herpes Zoster Torakalis

Penyakit Herpes Zoster Torakalis adalah infeksi virus yang menyerang pada bagian dada dan perut.

d. Penyakit Herpes Zoster Lumbalis

Penyakit Herpes Zoster Lumbalis adalah infeksi virus yang menyerang pada bagian bokong dan paha.

e. Penyakit Herpes Zoster Sakralis Penyakit Herpes Zoster Sakralis adalah infeksi virus yang menyerang pada bagian sekitar anus dan genitalia.

f. Penyakit Herpes Zoster Otikum Penyakit Herpes Zoster Otikum adalah infeksi virus yang menyerang pada bagian telinga.

\section{III.HASIL DAN PEMBAHASAN}

\section{A. Perancangan}

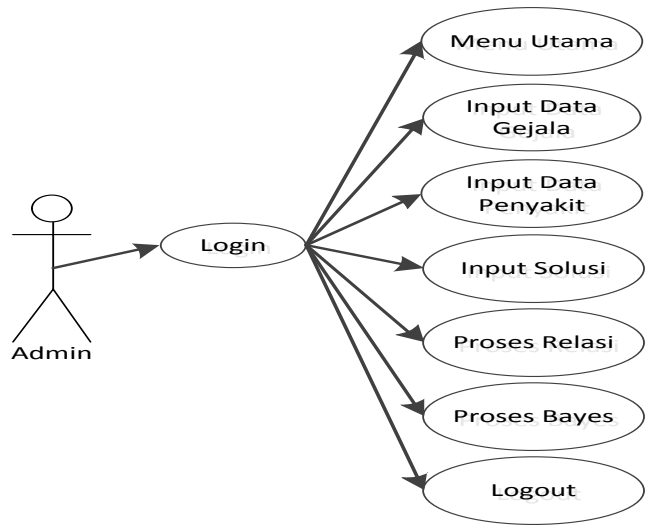

Gambar 1. Use Case Digram Perancangan Sistem

\section{B. Pembahasan}

Secara umum Teorema Bayes dengan E kejadiandan Hipotesis $\mathrm{H}$ dapat dituliskan dalam bentuk :

$$
\begin{aligned}
P(H i \mid E)= & \frac{P(E \cap H i) .}{\Sigma P(E \cap H j)} \\
& =\frac{P(E \mid H i) P(H i)}{\Sigma P(E \mid H j) P(H j)} \\
& =\frac{P(E \mid H i) P(H i)}{P(E)}
\end{aligned}
$$

Teorema Bayes dapat dikembangkan jika setelah dilakukan pengujian terhadap hipotesis kemudian muncul lebih daris satu evidence. Dalam hal ini maka persamaan nya akan menjadi:

$$
P(H \mid E, e)=P(H \mid E) \frac{P(e \mid E, H)}{P(e \mid E)}
$$

Keterangan :

e : evidence lama

$\mathrm{E}$ : evidence baru

$\mathrm{P}(\mathrm{H} \mid \mathrm{E}, \mathrm{e})$ : probabilitas hipotesis $\mathrm{H}$ benar jikamuncul evidence baru E dari evidence baru $\mathrm{E}$ dari evidence lamae.

$\mathrm{P}(\mathrm{H} \mid \mathrm{E})$ : probabilitas hipotesis $\mathrm{H}$ benar jikadiberikan evidence $\mathrm{E}$.

$\mathrm{P}(\mathrm{e} \mid \mathrm{E}, \mathrm{H})$ : kaitan antar e dan $\mathrm{E}$ jika hipotesis Hbenar.

$\mathrm{P}(\mathrm{e} \mid \mathrm{E})$ : kaitanantara e dan E tanpamemandang hipotesis apapun.

1. Logika Metode Bayes

Teorema Bayes menerangkan hubungan antara probabilitas terjadiny aperistwa A dengan syarat peristiwa $\mathrm{B}$ telah terjadi dan probabilitas terjadinya peristiwa $\mathrm{B}$ dengan syarat peristiwa A telah terjadi. Teorema ini didasarkan pada prinsip bahwa tambahan informasi dapat memperbaiki probabilitas. Teorema Bayes ini bermanfaat untuk mengubah atau memutakhirkan (meng-update) probabilitas yang dihitung dengan tersedianya data dan informasi tambahan[3].

2. Data Gejala Penyakit Herpes Zoster

Keberhasilan sistem pakar terletak pada pengetahuan dan bagaimana mengolah pengetahuan tersebut agar dapat ditarik sebuah kesimpulan. Pengetahuan yang diperoleh dari hasil wawancara di konversi ke dalam sebuah tabel jenis gejala penyakit Herpes Zoster dan gejalanya guna mempermudah proses pencarian solusi. Gejala penyakit Herpes Zoster dapat dilihat dari tabel berikut ini:

$$
\text { TABEL I. }
$$

\section{GEJALA PENYAKIT HERPES ZOSTER}

\begin{tabular}{lll}
\hline Kode & \multicolumn{1}{c}{ Gejala } & P01 \\
\hline G01 & Tubuh mengalami demam & \\
G02 & Nafsu menjadi berkurang & \\
G03 & Bercak berwarna putih & \\
\hline
\end{tabular}




\begin{tabular}{|c|c|}
\hline G04 & Kulit merah dan berisi nanah \\
\hline G05 & Terasa gatal \\
\hline G06 & Bersin \\
\hline G07 & Minyak berlebihan \\
\hline G08 & $\begin{array}{l}\text { Luka terbuka dan terasa sakit } \\
\text { Badan terasa lesu dan radang }\end{array}$ \\
\hline G09 & mata \\
\hline G10 & Demam \\
\hline
\end{tabular}

Bayes penyakit Herpes Zoster yang dipilih dengan menggunakan $\mathrm{R} 1$ dan $\mathrm{R} 2$

$\mathrm{CF}(\mathrm{R} 1, \mathrm{R} 2)=\mathrm{CF}(\mathrm{R} 1)+\mathrm{CF}(\mathrm{R} 2)-[(\mathrm{CF}(\mathrm{R} 1)$ $\mathrm{x} \mathrm{CF}(\mathrm{R} 2)]$

$=0.1+0.1-(0.1)(0.1)$

$=0.19$

Lalu kombinasikan dengan $\mathrm{R}$ ? selanjutnya,

yang pada contoh ini adalah R3 $\mathrm{CF}(\mathrm{R} 1, \mathrm{R} 2, \mathrm{R} 3)=\mathrm{CF}(\mathrm{R} 1, \mathrm{R} 2)+$

$\mathrm{CF}(\mathrm{R} 3)-[(\mathrm{CF}(\mathrm{R} 1, \mathrm{R} 2) \times \mathrm{CF}(\mathrm{R} 3)]$

$=0.19+0.05-(0.19)(0.05)$

$=0,24-0,0095$

$=0,2305(23 \%)$

Artinya, kombiasi R1, R2, dan R3 akan menghasilkan $23 \%$ kemungkinan kesimpulan penyakit Herpes Zoster terjadi.

3. Kesimpulan Gejala Penyakit Herpes Zoster

Kesimpulan gejala penyakit Herpes Zoster adalah tabel yang menyimpulkan dimana setiap gejala penyakit Herpes Zoster mempunyai analisis-analisis yang sama dengan gejala Herpes Zoster lainnya. Seperti pada tabel dibawah ini:

Nilai Teorema Buyes ini diambil dari 100 kasus yang terjadi dilapangan dan seberapa sering gejala tersebut muncul, lalu nilai gejala dibagi 100 maka hasilnya berupa pecahan. Berikut daftar nilai Nilai Teorema Buyes yang diberikan pakar :

TABEL II.

DAFTAR NILAI GEJALA PENYAKIT

\begin{tabular}{ccll}
\hline No & $\begin{array}{c}\text { Kode } \\
\text { Gejala }\end{array}$ & Daftar Gejala & $\begin{array}{l}\text { Nilai } \\
\text { Buyes }\end{array}$ \\
\hline 1 & & $\begin{array}{l}\text { Tubuh mengalami } \\
\text { demam }\end{array}$ & 0,7 \\
2 & G02 & $\begin{array}{l}\text { Nafsu menjadi } \\
\text { berkurang }\end{array}$ & 0,5 \\
3 & G03 & $\begin{array}{l}\text { Bercak berwarna } \\
\text { puth }\end{array}$ & 0,7 \\
4 & G04 & $\begin{array}{l}\text { Kulit merah dan } \\
\text { berisi nanah }\end{array}$ & 0,4 \\
5 & G05 & Terasa gatal & 0,6 \\
6 & G06 & Bersin & 0,3 \\
7 & G07 & Minyak berlebihan & 0,4 \\
8 & G08 & Luka terbuka dan & 0,6 \\
\hline
\end{tabular}

\begin{tabular}{llll}
\hline 9 & G09 & $\begin{array}{l}\text { Badan terasa lesu } \\
\text { dan radang mata }\end{array}$ & 0,9 \\
10 & G110 & Demam & 0,7 \\
\hline
\end{tabular}

Contoh Kasus :

Dilakukan pemeriksaan Gejala awal Herpes Zoster melitus yang terkena penyakit dengan gejala - gejala yang muncul sebagai berikut :

$\begin{aligned} \mathrm{G} 1 & =0.4 \mathrm{P}(\mathrm{E} \mid \mathrm{H} 1) \\ \mathrm{G} 2 & =0.4 \mathrm{P}(\mathrm{E} \mid \mathrm{H} 2) \\ \mathrm{G} 3 & =0.5 \mathrm{P}(\mathrm{E} \mid \mathrm{H} 3) \\ \mathrm{G} 3 & =0.5 \mathrm{P}(\mathrm{E} \mid \mathrm{H} 4) \\ \mathrm{G} 4 & =0.4 \mathrm{P}(\mathrm{E} \mid \mathrm{H} 5) \\ \mathrm{G} 6 & =0.3 \mathrm{P}(\mathrm{E} \mid \mathrm{H} 6)\end{aligned}$

Kemudian mencari nilai semesta dengan menjumlahkan dari hipotesa di atas :

$$
\begin{aligned}
\sum_{G 10}^{6}= & G 1+G 4+G 6+G 7+G 8+G 10 \\
& =0.4+0.4+0.5+0.5+0.4+0.3=2.5
\end{aligned}
$$

Setelah hasil penjumlahan di atas diketahui, maka didapatlah rumus untuk menghitung nilai semesta adalah sabagai berikut :

$$
\begin{aligned}
& P(H 1)=\frac{H 1}{\sum_{K=1}^{6}}=\frac{0.4}{2.5}=0.16 \\
& P(H 2)=\frac{H 2}{\sum_{K=1}^{6}}=\frac{0.4}{2.5}=0.16 \\
& P(H 3)=\frac{H 3}{\sum_{K=1}^{6}}=\frac{0.5}{2.5}=0.2 \\
& P(H 4)=\frac{H 4}{\sum_{K=1}^{6}}=\frac{0.5}{2.5}=0.2 \\
& P(H 5)=\frac{H 5}{\sum_{K=1}^{6}}=\frac{0.4}{2.5}=0.16 \\
& P(H 6)=\frac{H 6}{\sum_{K=1}^{6}}=\frac{0.3}{2.5}=0.12
\end{aligned}
$$

Setelah nilai $\mathrm{P}(\mathrm{Hi})$ diketahui, probabilitas hipotesis $\mathrm{H}$ tanpa memandang evidence apapun, makalangkah selanjutnya adalah :

$$
\begin{aligned}
& \sum_{K=1}^{6}=P(H i) * P(E \mid H i-n) \\
& =(\mathrm{P}(\mathrm{H} 1) * \mathrm{P}(\mathrm{E} \mid \mathrm{H} 1))+(\mathrm{P}(\mathrm{H} 2) * \mathrm{P}(\mathrm{E} \mid \mathrm{H} 2))+ \\
& (\mathrm{P}(\mathrm{H} 3) * \mathrm{P}(\mathrm{E} \mid \mathrm{H} 3))+(\mathrm{P}(\mathrm{H} 4) * \\
& \mathrm{P}(\mathrm{E} \mid \mathrm{H} 4))+(\mathrm{P}(\mathrm{H} 5) * \mathrm{P}(\mathrm{E} \mid \mathrm{H} 5))+(\mathrm{P}(\mathrm{H} 6) \\
& * \mathrm{P}(\mathrm{E} \mid \mathrm{H} 6)) \\
& =(0.16 * 0.4)+(0.16 * 0.4)+(0.2 * 0.5)+ \\
& (0.2 * 0.5)+(0.16 * 0.4)+(0.12 * \\
& 0.3)
\end{aligned}
$$

Langkah selanjutnya ialah mencari nilai $\mathrm{P}(\mathrm{Hi} \mid \mathrm{E})$ atau probabilitas hipotesis Hi benar jika diberikan evidence $\mathrm{E}$

$P(H 1 \mid E) \frac{0.4 * 0.064}{0.428}=0.059813$ 


$$
\begin{aligned}
& P(H 2 \mid E) \frac{0.4 * 0.064}{0.428}=0.059813 \\
& P(H 3 \mid E) \frac{0.5 * 0.1}{0.428}=0.093458 \\
& P(H 4 \mid E) \frac{0.5 * 0.1}{0.428}=0.093458 \\
& P(H 5 \mid E) \frac{0.4 * 0.064}{0.428}=0.059813 \\
& P(H 6 \mid E) \frac{0.3 * 0.036}{0.428}=0.033645
\end{aligned}
$$

Setelah seluruh nilai $\mathrm{P}(\mathrm{Hi} \mid \mathrm{E})$ diketahui, maka jumlahkan seluruh nilai bayesnya dengan rumussebagai berikut :

$\sum_{k=1}^{N}$ bayes = bayes $1+$ bayes + bayes $3+$ bayes + bayes $5+$ bayes 6
$=(0.4 * 0.059813)+(0.4 * 0.059813)+(0.5$
$* 0.093458)+(0.5 * 0.093458)+(0.4 *$
$0.059813)+(0.3 * 0.033645)$
$=0.059812+0.059812+0.11682+0.11682+$
$0.059812+0.123360033$
$=0,535359 * 100 \%$
$=43.5359 \%$
Berdasarkan

Keteramgan :

Jika nama gejala satu disingkat dengan G01, Jika penyakit satu maka disingkat dengan P1 Basis Aturan
Dalam hal ini gejala dekelompokam dalam beberapa bagian, basis penegatahuan, basis aturan beserta rule, berikut pembahasannya.

Basis aturan disesuaikan dengan pertanyaan penyakit dengan kode gejala dan id penyakit, misalnya G01, G02, G03 maka peluang penyakit yang disimpulkan adalah P1 yaitu penykit Herpes Zoster Servikalis. Basis aturan dari aplikasi sistem pakar diagnosa penyait Herpes Zoster dapat dilihat pada tabel IV.

TABLE IV.

\begin{tabular}{|c|c|c|c|}
\hline $\begin{array}{l}\text { Id } \\
\text { Penyaki } \\
\text { t }\end{array}$ & IF & $\begin{array}{c}\text { THE } \\
\mathbf{N}\end{array}$ & rangan \\
\hline P1 & G1,G2,G5 & P01 & $\begin{array}{l}\text { Herpes } \\
\text { Zoster } \\
\text { Servikali } \\
\text { s }\end{array}$ \\
\hline P2 & $\begin{array}{c}\text { G6,G10,G } \\
1\end{array}$ & P02 & $\begin{array}{l}\text { Herpes } \\
\text { Zoster } \\
\text { Torakalis }\end{array}$ \\
\hline P3 & $\mathrm{G} 2, \mathrm{G} 6, \mathrm{G} 7$ & P03 & $\begin{array}{l}\text { Herpes } \\
\text { Zoster } \\
\text { Lumbalis }\end{array}$ \\
\hline
\end{tabular}
BASIS ATURAN

\begin{tabular}{clc}
\multicolumn{3}{c}{ BASIS ATURAN } \\
\hline $\begin{array}{c}\text { Kode } \\
\text { Gejala }\end{array}$ & \multicolumn{1}{c}{ Gejala } & $\begin{array}{c}\text { Id } \\
\text { Penyakit }\end{array}$ \\
\hline G01 & $\begin{array}{l}\text { Tubuh } \\
\text { mengalami } \\
\text { demam }\end{array}$ & P1 \\
G02 & $\begin{array}{l}\text { Nafsu } \\
\text { menjadi } \\
\text { berkurang }\end{array}$ & P1 \\
& $\begin{array}{l}\text { Bercak } \\
\text { berwarna } \\
\text { putih }\end{array}$ & P1 \\
G03 & \\
\hline
\end{tabular}

TABEL V.

PENYAKIT HERPES ZOSTER

\section{Implementasi Sistem}

1. Tampilan Form Login

Form login adalah form yang akan tampil pada saat user memilih dokter. Pada form ini dokter diharuskan mengisiUser IddanPassword pada form login. Adapun tampilan dari form login adalah seperti terlihat pada gambar berikut: 


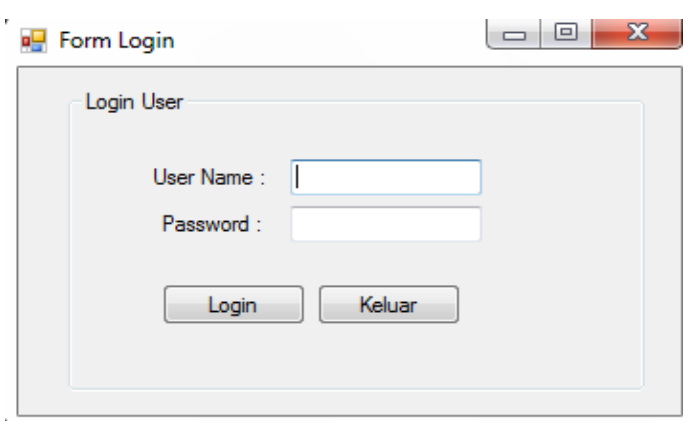

Gambar 2. Form Login

\section{Form Menu Utama}

Form menu utama tampil apabila dokter atau pasien memilih menu pada menu awal. Menu utama bagi dokter berupa submenu berupainput data pasien, data penyakitdan data diagnosa, submenu basis pengetahuan, submenu laporan dan submenu keluar. Menu utama bagi pasien berupa input data pasien dan dilanjutkan konsultasi pasien.

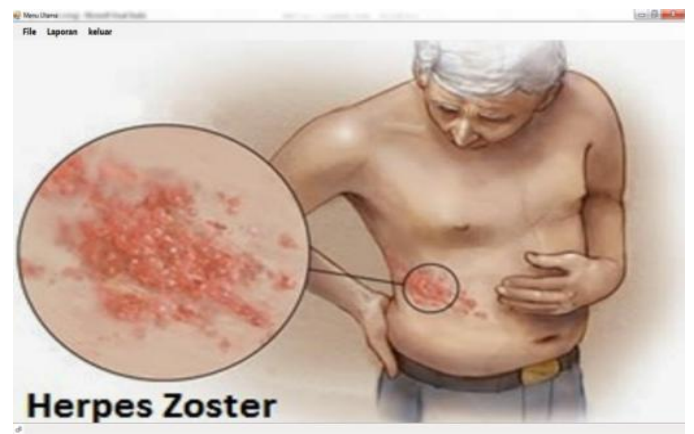

Gambar 3. FormMenu UtamaDokter Dan Pasien

3. Form Penyakit

Form penyakit adalah form yang berguna untuk menyimpan, mengubah dan menghapus data penyakit yang diinput oleh dokter melalui sistem pakar langsung ke database. Adapun tampilan keluaran dari form penyakit adalah sebagai berikut :

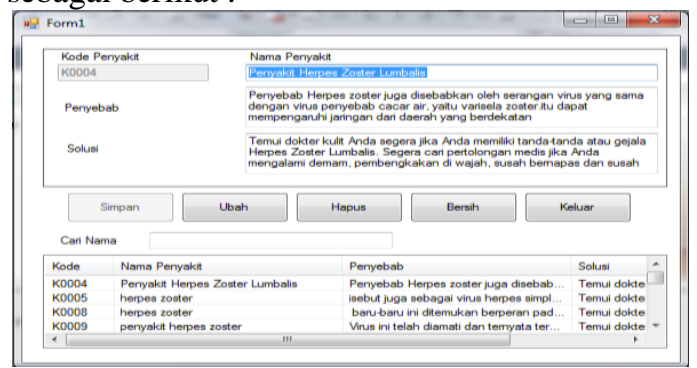

Gambar 4. Form Penyakit

\section{Form Pasien}

Form pasien adalah form yang berguna untuk menginput mengubah dan menghapus data Pasien langsung kedatabase. Adapun tampilan keluaran dari form pasien adalah sebagai berikut :

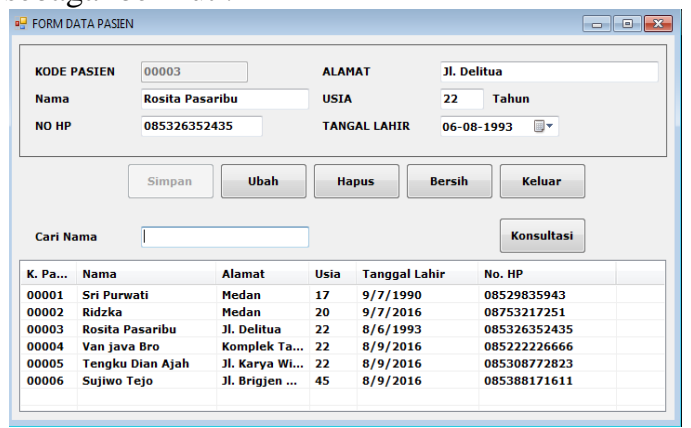

\section{Gambar 5. Form Pasien}

\section{Form Konsultasi}

Form konsultasi adalah form yang digunakan pasien untuk melakukan konsultasi langsung pada sistem pakar. Adapun tampilan keluaran dari form konsultasi adalah sebagai berikut :

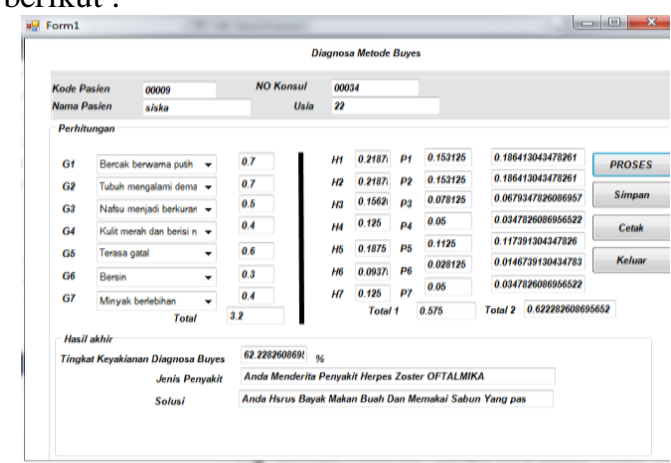

\section{Gambar 6. Form Konsultasi}

6. Form Laporan Konsultasi Pasien

Form laporan konsultasi pasien adalah form yang digunakan pasien untuk menampilkan hasil konsultasi pasien pada sistem pakar. Adapun tampilan keluaran dari form laporan konsultasi pasien adalah sebagai berikut :

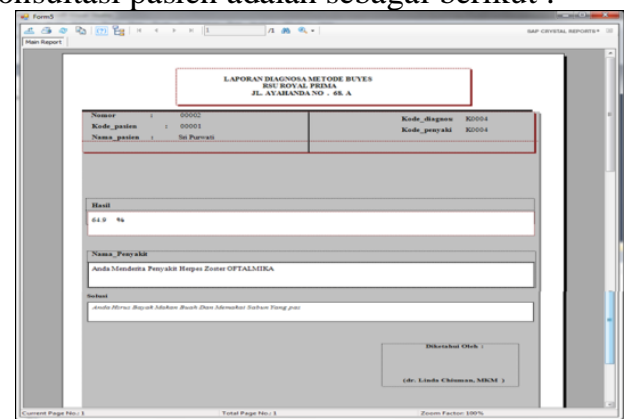

Gambar 7. Form Laporan Konsultasi Pasien

7. Form Laporan Keseluruhan Pasien

Form laporan keseluruhan pasien adalah form yang digunakan dokter untuk menampilkan hasil konsultasi seluruh pasien pada sistem pakar. Adapun tampilan keluaran 
dari form laporan konsultasi pasien adalah sebagai berikut :

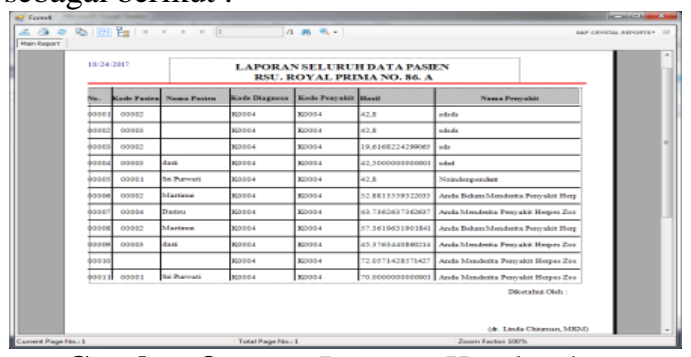

Gambar 8. Form Laporan Keseluruhan Konsultasi Pasien

Dalam pengujian berikut hasil implementasi mendiagnosa penyakit Herpes Zoster menggunakan aplikasi system pakar dengan metode Baye sdidapat proses yang memberikan hasil akurat dalam pengujian data sampel dari bahan penelitian ini. Gambar dibawah ini merupakan pengujian sistem yang telah di uji coba pada Rumah Sakit Umum Royal Prima Medan. Nilai keyakinan jenis penyakit pada uji coba system pakar untuk konsultasi pasien dengan jawaban gejala 1 , gejala 2 , gejala 3 , gejala 5 , gejala 7 , gejala 9 dan gejala 10 mendapatkan hasil $62,22 \%$ atau lebih tingkat keyakinan penyakit pasien pada sistem.

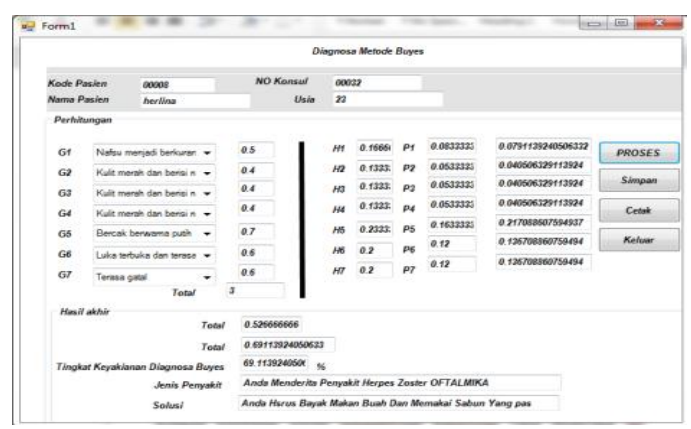

Gambar 9. Proses Pengujian

\section{IV.KESIMPULAN}

Berdasarkan hasil pembahasan teori pada sistem pakar mendiagnosa penyakit herpes zoster menggunakan metode teorema bayes dapat disimpulkan sebagai berikut:

1. Sistem pakar dapat mendiagnosa penyakit herpes zoster, namun masih belum bisa dijadikan acuan karena ini hanya membantu pasien dengan hasil proses metode teorema bayes, untuk lebih pasti konsultasi langsung dengan dokter spesial.

2. Dalam mediagnosa penyakit herpes zoster berdasarkan gejala-gejala yang ditemukan pada tipe penyakit herpes zoster, sistem juga mampu memberikan informasi untuk solusi pengobatan penyakit.

\section{REFERENSI}

[1] T. Sutojo, S.Si., M.Kom., Edy Mulyanto, S.Si., M.Kom., Dr. Vincent Suhartono,2011, Kecerdasaan Buatan, , Yogyakarta, Andi

[2] Kristanto Andi, 2004, Kecerdasan Buatan, Yogyakarta, Grahallmu

[3] http://duniafitnes.com/training-plans/bodyshaping.html diaksespadatanggal 10 April 2012 pukul 15.00148

[4] Maybury MT, 2004, New Direction In Question Answering, AAAI Press/The MIT Press

[5] Sihotang, Hengki Tamando. "Perancangan Aplikasi Sistem Pakar Diagnosa Diabetes Dengan Metode Bayes." Jurnal Mantik Penusa, vol. 1, no. 1, 2017, pp. 36-41, http://e-

jurnal.pelitanusantara.ac.id/index.php/mant ik/article/view/280.

[6] Sihotang, Hengki Tamando. "Sistem Pakar Untuk Mendiagnosa Penyakit Pada Tanaman Jagung Dengan Metode Bayes." Journal Of Informatic Pelita Nusantara, vol. 3, no. 1, 2018, pp. 1-9, http://ejurnal.pelitanusantara.ac.id/index.php/JIPN /article/view/281/178.

[7] Simangunsong, Agustina, et al. "Perancangan Aplikasi Sistempakar Menggunakan Metode Bayes Untuk Diagnosa Gejala Asma Pada Puskesmas Deli Tua." Journal of Informatics Pelita Nusantara, vol. 2, no. 1, 2017, pp. 14-21, http://e-

jurnal.pelitanusantara.ac.id/index.php/JIPN /article/view/273/171.

[8] Sihotang, Hengki Tamando. "Sistem Pakar Mendiagnosa Penyakit Kolesterol Pada Remaja Dengan Metode Certainty Factor (Cf) Berbasis Web." Jurnal Mantik Penusa, vol. 15, no. 1, 2014, pp. 16-23. 
